\title{
MENTAL ACCOUNTING IN THE CONTEXT OF SAVINGS AND CREDIT DECISIONS. EVIDENCE FROM POLAND
}

The main objective of this article is to identify and analyze the factors favouring the attitude of mental accounting in a wider sense. The analysis also helped identify the advantages and disadvantages resulting from the adoption of such an attitude as well as an assessment of the decisions made from the economic and psychological perspective. The following hypothesis was formulated: individuals characterised by debt aversion do not show an inclination to adopt the attitude of mental accounting in a wider sense. The core research method used in the study is logistic regression. The necessary empirical data of quantitative and qualitative nature were collected through surveys carried out in January 2013 through Computer Assisted Web Interview on a sample of 1000 Poles aged 15 or above. Other methods applied include a review and critical analysis of the subject literature. The study shows that among the factors identified, the strongest determinants of the mental accounting attitude are: having debt, having savings, debt aversion and the amount of monthly net income achieved. Both having debt and high monthly net income increase the likelihood of adoption of the attitudes of mental accounting, while the other factors have the opposite effect. In addition to the above factors, the behaviour of the people likely to do mental accounting is also affected by the objective of consumer spending as well as the time and the purpose of saving. Adopting the mental accounting attitude has some advantages, the most important of which is the fact that the attitude builds the ability to systematically manage the household budget and facilitates the efficient planning of income and expenditure as well as consistently sticking to previous decisions. Creating mental accounts helps organize personal finance and thus promotes achieving the goals of saving; this means that the psychological need of safety is met. With regard to the disadvantages of adopting the said attitude, it should be emphasized that the decision to protect savings, which results in the need for borrowing, exposes the individual to the risks of debt servicing and extra costs, which in extreme cases may bring about an over-indebtedness.

Keywords: mental accounting, non-fungibility, financial decisions, logistic regression

JEL Classifications: D10, D14, G21

DOI: $10.15611 /$ aoe.2019.2.15

\footnotetext{
* Department of Finance, Wroclaw University of Economics and Business.

** Department of Finance and Accounting, Wroclaw University of Economics and Business.
} 


\section{INTRODUCTION}

In one of his publications, R. H. Thaler claimed: "Economics can be distinguished from other social sciences by the belief that most (all?) behavior can be explained by assuming that agents have stable, well-defined preferences and make rational choices consistent with those preferences in markets that (eventually) clear" (Thaler, 1990, p. 193). This quotation is still valid and the issues related to rational/irrational choices are still an important and current problem. The problem refers not only to economics but to finance, too.

The adoption of the model homo economicus $\mathrm{R}$. H. Thaler refers to made it possible to explore many issues, but for years scientists have been pointing out that in certain areas the assumptions adopted restrict the proper evaluation of various phenomena and their effective prediction (Kahneman and Tversky, 1974; Kahneman and Tversky, 1979; Gilovich et al., 2002; Braun, 2006; Khandakar, 2014). However, it seems that over time, as a result of the profound changes occurring in the global economy since the 1990s and of their impact on the behaviour of individuals and the functioning of markets, the mismatch arising from the assumptions adopted within the homo economicus concept is getting stronger and stronger (Braun, 2006). In recent years, the financial crisis has intensified the discussion on the need to modify the current paradigm of economics and finance. In fact, it seems that derogations from the principles adopted, which the researchers identify and refer to as anomalies, are gaining in importance.

The anomalies constitute a set of behaviours that are non-compliant with the assumptions defining rational human functioning. Studies that abandon the traditional assumptions on the maximization of the anticipated utility by rational investors in efficient markets constitute the area of interest of behavioural finance (Ritter, 2003). One of the problems for which the occurrence of deviations is continuously examined and the results seem to be extremely important, even from the point of view of the recent financial crisis, are financial decisions.

On the one hand, financial decisions should be seen as common/ordinary decisions made almost daily by every household and every independent individual, but on the other hand it should be remembered that such decisions are very complex. They are determined by a wide variety of factors (including those beyond the individuals' control) and have various time horizons, which gives rise to a number of very significant consequences such as the quality of life in retirement or the ability to cope with difficult 
situations like illness or job loss. While observing decision-making methods and the results of the decisions made, it is very easy to see that they often cannot be classified as rational.

Every financial decision can be placed at a specific point between two extreme and explicit attitudes - fear and greed (Shefrin, 2002). An individual driven by fear will be inclined toward a preventive attitude, a person reluctant to go into debt but with high inclination to save. A person motivated by greed will, in turn, be characterised by short-sightedness, a preference for current consumption, and at the same time willing to get into debt (Ainslie, 1975; Swacha-Lech, 2012). Some extremely intriguing research results are produced by an analysis of human behaviour in terms of decisions related to both credit and savings. One of the interesting issues observed in the context of financial decision-making is mental accounting which seems to be particularly evident in credit and savings decisions. Research shows that as a result of mental accounting, individual behaviour is in apparent conflict with the principle of money fungibility (Thaler, 1985; Thaler, 1990; Thaler, 1999; Shefrin and Thaler, 2004; Abeler and Marklein, 2010; Gou et al., 2013). The phenomenon can be seen in two different perspectives - in a strict and a wider sense. This follows from Thaler's general theory (Thaler, 1990) that where people do mental accounting, they consider money non-fungibility (i.e. mental accounting in the strict sense). In the literature, however, further studies can be found demonstrating that there may be some flows between mental accounts, and thus there is a certain degree of fungibility (i.e. mental accounting in a wider sense). In this article the latter interpretation of mental accounting has been applied.

This article deals with the problem of mental accounting within a particular area of financial decisions related to savings and credit. The study focused on identifying a set of people whose behaviour is indicative of the cognitive process known as mental accounting, as opposed to the principle of money fungibility, and on analysing these modes of behaviour. The main aim of this article is to identify and analyze the factors favouring the attitude of the broadly interpreted mental accounting. This analysis also identified the advantages and disadvantages of such an attitude and helped assess the financial decisions from the economic and psychological viewpoints. The following hypothesis was formulated: individuals characterised by debt aversion do not show an inclination to adopt the attitude of mental accounting in a wider sense.

The basic research method used in the study was the method of logistic regression. The necessary quantitative and qualitative empirical data were collected through surveys carried out using the Computer Assisted Web 
Interview (CAWI) on a sample of 1,000 Polish Internet users aged 15 or above. Other methods applied include a review and critical analysis of the subject literature.

The subjects were placed in a hypothetical situation which combined savings and indebtedness, and then were asked to indicate the response best corresponding to their preferences. Using an appropriate set of questions it was possible to reveal the respondents' preferences in relation to issues such as aversion to debt, prudence or short-sightedness.

\section{THE NATURE OF MENTAL ACCOUNTING PROBLEM - LITERATURE REVIEW}

Mental accounting is the term introduced by Thaler (1985) and means the cognitive process, or more precisely the set of cognitive operations, used by individuals and households to organize, evaluate, and keep track of financial activities. It involves creating in the mind specific accounts. People categorize their activities into mental accounts and make decisions within the context of these spending and saving categories, rather than grouping all decisions together and optimizing consumption choices over a life-long horizon (Milkman and Beshears, 2009). Graham and Isaac (2002) emphasize that using mental accounts restricts the allocation of certain types of income to certain types of consumption. Explaining the nature of mental accounting, R. H. Thaler indicates that the goals of using this cognitive process are similar to those which motivate organizations to use managerial accounting. The following goals are distinguished: keeping track of where their money is going and keeping spending under control, so mental accounting means a description of the ways individuals do these things (Thaler, 1999). Whereas financial and managerial accounting records financial transactions in books, and analyses and reports the results, mental accounting describes the way ordinary people carry out such activities (Antonides and Ranyard, 2017).

The expression of mental accounting is inextricably linked with the term of fungibility. Thaler (1990) thinks that fungibility is the notion that money has no labels. He notes that money in one mental account is not a perfect substitute for money in another account, while according to neoclassical theory and the lifecycle model, the marginal propensity to consume (MPC) for all types of wealth is supposed to be equal (assuming no transitions cost and so on). Then the creating of these specific accounts is connected with the non-fungibility effect. Thaler (1999) also finds three components of mental accounting which violate the economic principle of fungibility: 
- the way in which the individuals perceive and experience the outcomes,

- the assigning of particular financial resources and expenditures to specific accounts,

- the frequency with which the accounts are evaluated and the way of defining them (narrow or broad).

The first element shows the differences with regard to the individual perception of the value of money depending on the circumstances. It reflects the different way of perceiving money earned through hard work and an equivalent amount won in a lottery, as well as the different way of assessing products offered and the reaction to the products on sale.

Relating to the second component it can be stated that the main divisions of mental accounts include sources of finding, consumer items and saving patterns (Gou et al., 2013). Kivetz (1999) emphasizes that consumers tend to label resources (regular income vs. windfall gains) and consumption (necessary vs. hedonic consumption), revealing also some systematic preferences for matching certain accounts (they prefer to pay for luxurious consumption with windfall gains). The grouping of mental accounts referring to saving patterns can be shown through the division of wealth into fixed accounts and interim accounts. This division is based on saving goals. People tend not to transfer money from the fixed account in order to meet temporary consumption demands (Gou et al., 2013).

The third element refers to the frequency with which individuals evaluate mental accounts, as well as to the attitude towards grouping them. The evaluation of accounts can be done within different time periods: daily, weekly, monthly or yearly. Besides that, people demonstrate significant differences in approaches to mental accounting. Some of them are characterized by a narrow attitude, whereas others - a broad one.

Thaler (1990) indicates that in general, one can distinguish three fundamental, broad accounts: current income account ( $I)$, asset account $(A)$, and future income $(F)$. Distinguishing these three accounts allowed him to present the nature of the mental accounting phenomenon, providing at the same time a solid base for other researchers exploring this field. Additionally, the introduction of separate accounts including: current income account, asset account and future income allowed Thaler to create perfect conditions in order to prove the non-fungibility effect. Thaler (1990) notes that the $M P C$ from $C$ (when $\mathrm{C}$ is consumption) is close to unity, from $F-$ is close to 0 and from $A$ is located between these two values, which can be expressed in the following way: 


$$
0 \approx \partial C / ð F<ð C / ð A<ð C / ð I \approx 1
$$

Mental accounting has become an important issue in finance and its nature has been explored by many researchers. Table 1 presents the selected studies on mental accounts conducted by scientists.

Table 1

The selected directions of research examining the problem of mental accounting

\begin{tabular}{|c|c|}
\hline Key problem & The most important conclusions \\
\hline 1 & 2 \\
\hline $\begin{array}{l}\text { Relaxation } \\
\text { of normative } \\
\text { principle of } \\
\text { fungibility }\end{array}$ & $\begin{array}{l}\text { - Thaler }(1985 ; 1999) \text { uses the concept of mental accounting in his studies on a } \\
\text { behaviourally based theory of consumer choice. Relaxation of normative principle } \\
\text { of fungibility is one of the most significant outcomes observed in these studies. } \\
\text { Based on human behaviour observations, he noted that people may prefer to } \\
\text { receive a gift in kind over a gift in cash; } \\
\text { - Abeler and Marklein (2017) conducted a controlled laboratory experiment and prove } \\
\text { that when a label is attached to a part of an individual's budget, the subjects change } \\
\text { consumption according to the suggestion of this label and violate fungibility. People } \\
\text { with lower mathematical abilities are more likely to violate this principle. }\end{array}$ \\
\hline $\begin{array}{l}\text { Mental } \\
\text { accounting vs. } \\
\text { consumption }\end{array}$ & $\begin{array}{l}\text { - Prelec and Loewenstein (1998) propose the "double-entry" mental accounting } \\
\text { model theory. This approach emphasizes the nature of reciprocal interactions } \\
\text { between the pleasure derived from consumption and the pain of paying through the } \\
\text { introduction of: "net" utility derived from consumption after subtracting the } \\
\text { disutility of associated payments and "net" disutility of payments after subtracting } \\
\text { the utility of associated consumption. The authors pay attention to the arising } \\
\text { tensions between hedonic efficiency and decision/outcome efficiency; } \\
\text { - In the research on consumer behaviour related to choices between cash amount and } \\
\text { an equal or lower valued luxury, hedonic item, Kivetz (1999) uses not only mental } \\
\text { accounting but also reason based-choice. He claims that the interaction between } \\
\text { reasoning and mental accounting can help counteract the pain of paying and a } \\
\text { tendency to underconsume luxury goods; } \\
\text { - Davies et al. (2009) explore the problem of remittances. They notice that this } \\
\text { wealth group is characterized by lower MPC than other income and is widely used } \\
\text { to finance education; } \\
\text { - Using the three incentive-compatible experiments (e.g. fMRI) Mazar et al. (2017) } \\
\text { claim that the concept of pain of paying is more than a theoretical idea. The } \\
\text { examined people experience a literal, physical pain; } \\
\text { - Erat and Bhaskaran (2012) investigate the problem of mental accounting in the } \\
\text { context of add-on purchase decisions. The formulated model shows how the mental } \\
\text { accounting associated with a base product impacts on a consumer's add-on purchase } \\
\text { decision. }\end{array}$ \\
\hline $\begin{array}{l}\text { Dynamic } \\
\text { pricing }\end{array}$ & $\begin{array}{l}\text { - Hu et al. (2015) investigate dynamic pricing problems for single-flight and multiple } \\
\text { flights in the context of mental accounting, using the dynamic programming method. } \\
\text { The studies show that the passenger mental accounting depth has a positive effect on } \\
\text { the optimal prices in cases of single and multiple flights. }\end{array}$ \\
\hline
\end{tabular}


\begin{tabular}{c|c}
\hline 1 & 2 \\
\hline Mental & - Odean (1998) analyzed 10,000 accounts at a large discount brokerage house from
\end{tabular} accounting January 1987 to December 1993 and confirmed the phenomenon of mental among the accounting among investors. He observed the disposition effect which is typical investors for investor's behaviour;

- Grinblatt and Han (2005) consider a model of equilibrium prices in which a group of investors is subject to prospect theory and mental accounting. The model is consistent with the empirical evidence on the disposition effect. The authors proved the existence of a significantly positive cross-sectional relation between a stock's capital gains overhang and its future stock return;

- Seiler et al. (2010) discover that people do experience a greater willingness to sell when investments cross the breakeven threshold and move into positive territory and that this preference set does in fact consider the total costs to dispose of the asset. The authors prove that people consider their disposition decision in net, not gross, terms and perceive commissions as part of mental accounting tests;

- Bhootra and Hur (2012) investigate the role of cointegration between stock prices and their estimated fundamental values in return momentum. The authors prove that the positive relationship between capital gains overhang and future stock returns is significantly stronger among the non-cointegrated group of stocks. In cases of the cointegrated stocks, the slower the speed of adjustment to the cointegrating equilibrium, the greater (smaller) the future return of stocks with unrealized capital gains (losses).

Mental $\quad$ - Milkman and Beshears (2009) examine people's consumer buying behaviour accounting in two different situations - with a \$10-off coupon and without it. The coupon is vs. windfalls a small windfalls and according to the lifecycle model should not influence decisions as it constitutes meaningless changes to lifetime wealth. The observation of real consumers' behaviour shows that the windfalls are spent on goods which are not typical of their purchases that would not be bought otherwise;

- Levav and McGraw (2009) propose the approach derived from traditional mental accounting theory, relating to the fact that the way of obtaining income affects the way how the income is going to be used. They note that there are some exceptions to this rule connected with some emotions companying the income. Money inherited after the death of a relative constitutes a windfall, however it is not used as a typical extra cash injection. Bearing in mind what its origin is, individuals tend to make utilitarian or virtuous expenditures.

Self-regulation $\quad$ - Koch and Nafziger (2014) deal with the issue of self-regulation in the context of problem mental accounting and shows how the success of self-regulation depends on the type of mental accounting in which a person evaluates goal related outcomes narrow or broad. The authors prove that narrow mental accounting should correlate with better self-regulation;

- Koch and Nafziger (2016) come back to the problem of mental accounting, narrow bracketing and the self-regulation problem. They demonstrate that the phenomena of setting narrow goals or narrow mental budgets seem not to reflect choice errors due to low cognitive reflection. Moreover, the authors claim that they could be perceived as tools to overcome self-control problems.

\begin{tabular}{|c|c|}
\hline $\begin{array}{l}\text { Mental } \\
\text { accounting } \\
\text { of time }\end{array}$ & $\begin{array}{l}\text { - Rajagopal and Rha (2009) investigate the ways in which time is perceived and } \\
\text { tracked, and conclude that people create mental accounts for time like they do for } \\
\text { money and attempt to balance their time across work and non-work activities. }\end{array}$ \\
\hline $\begin{array}{l}\text { Mental } \\
\text { accounting } \\
\text { vs. credit } \\
\text { decisions }\end{array}$ & $\begin{array}{l}\text { - Ranyard et al. (2006) investigate the role of different measures of the cost of credit } \\
\text { for consumer credit policy. They notice that total cost is more important for } \\
\text { repayment plan decisions, since consumers often represent specific credit plans in } \\
\text { terms of total mental accounts and recurrent budget period accounts are used to } \\
\text { evaluate monthly repayments and anticipate future goals and hazards. }\end{array}$ \\
\hline
\end{tabular}


Table 1, cont.

\begin{tabular}{|c|c|}
\hline 1 & 2 \\
\hline $\begin{array}{l}\text { The } \\
\text { intertemporal } \\
\text { choice }\end{array}$ & $\begin{array}{l}\text { - Karlsson et al. (1997) show that people are unwilling to pay for a good in cash } \\
\text { after an income decrease, even though they have access to savings; } \\
\text { - Selart et al. (1997) analyse people's behaviour in the context of the Behavioural } \\
\text { Life Cycle Hypothesis and the theories of intertemporal choice. The paper shows } \\
\text { that in the case of income decrease, respondents were more willing to cut down on } \\
\text { their propensity to consume than to raise it when faced with an income increase. In } \\
\text { addition, when the changes of income took place immediately, people adjusted } \\
\text { their propensity to consume the most, which proves the fact that in some aspects } \\
\text { the theories of intertemporal choice could explain the people's behaviour better } \\
\text { than BHCL; } \\
\text { - Shafir and Thaler (2006) investigate issues of delayed consumption. They note that } \\
\text { the consumption of goods is coded in a different way. The purchase of wine is } \\
\text { typically perceived as an "investment" and the planned consumption as "free", } \\
\text { while when it is not consumed as planned, people treat this event as the cost of } \\
\text { replacing the good. }\end{array}$ \\
\hline $\begin{array}{l}\text { Mental } \\
\text { accounting and } \\
\text { retirement } \\
\text { savings } \\
\text { behaviour }\end{array}$ & $\begin{array}{l}\text { - Benartzi and Thaler (2001) proved that mental accounting affects the management } \\
\text { of company stock too. People create a special account for them and perceive them } \\
\text { as a "unique asset class"- - neither stocks nor bonds; } \\
\text { - Benartzi and Thaler (2007) observed that individuals treat the amounts they have } \\
\text { already accumulated in the pension plan and the amounts they have not yet } \\
\text { contributed in a different way. The difference in allocation of this money results } \\
\text { from creating a separate mental account for "old" and "new" money; } \\
\text { - Card and Ransom (2007) explore the differences in people's decisions depending } \\
\text { on the person assigned to contribution pensions. The individuals use separate } \\
\text { mental accounts for employers and employees' contributions. These two accounts } \\
\text { are characterized with a higher degree of substitutability between them, while } \\
\text { between supplemental savings and employer pension a lower degree of } \\
\text { substitutability is observed. }\end{array}$ \\
\hline $\begin{array}{l}\text { Gift cards and } \\
\text { mental } \\
\text { accounting }\end{array}$ & $\begin{array}{l}\text { - Assuming that the knowledge about accounting differs between people who have } \\
\text { never studied accounting (non-accountants) and those with an accounting } \\
\text { educational background (accountants), the author proves this knowledge can be } \\
\text { really helpful in rational decision-making (Shanti, 2017); } \\
\text { - On the basis of six studies, Reinholtz et al. (2015) prove that gift cards have an } \\
\text { influence on changing preferences. The authors observe customers' greater } \\
\text { preferences for products they perceive to be more typical of the retailer. }\end{array}$ \\
\hline $\begin{array}{l}\text { The complexity } \\
\text { of consumer } \\
\text { problems }\end{array}$ & $\begin{array}{l}\text { - Gilboa et al. (2010) suggest that people use mental accounting, however, for } \\
\text { fundamentally different reasons than those pointed by Thaler, who claims that } \\
\text { individuals create these accounts to keep spending under control. The researchers } \\
\text { state that people are as coherent as in the neoclassical model, but face complexity } \\
\text { constraints in making decisions. }\end{array}$ \\
\hline $\begin{array}{l}\text { Mental } \\
\text { budgeting }\end{array}$ & $\begin{array}{l}\text { - The results of the study of } 201 \text { SMEs randomly selected from the city of } \\
\text { Chittagong, Bangladesh and interviewed using a structured questionnaire, show } \\
\text { that mental budgeting has a significant influence on the financial management of } \\
\text { SMEs (Hoque and Ulku, 2017). }\end{array}$ \\
\hline
\end{tabular}

Source: own study. 
The great significance of mental accounting for research on decision behaviour is proved by the fact that it constitutes one of the basic assumptions of the Behavioural Life Cycle Hypothesis (BLCH), formulated by Shefrin and Thaler (1988). This theory was created as the answer to the imperfection of the Life Cycle Hypothesis (LCH) suggested by Modigliani and Brumberg (1954) and the Permanent Income Hypothesis (PIH), proposed by Friedman (1957). Both theories are termed as life cycle models.

The Behavioural Life Cycle Hypothesis derives from the analysis of real human behaviour. Shefrin and Thaler (1988), incorporating the behavioural finance achievements as a descriptive science, offered a new, alternative approach to the issues related to consumption and savings. Apart from mental accounting, BLCH is based on self-control and framing. The concept of self-control suggests the existence of "controller" and "controllee". Whereas Schelling (1978) claims that people behave as if they experienced a never-ending fight between a different "self" (egonomics), H. Shefrin and R. Thaler perceive the decisions taken by individuals as a result of the conflict between a far-sighted planner and a 'myopic' doer. The conflict arises because the doer's preferences are always short-sighted and opposite to the planner's references. Decisionframing constitutes the specific bias in the decision process which involves the relation between the result of choices made and the form of problem presentation (Thaler, 1990). The framing effect is shown by the prospect theory which was formulated by Kahneman and Tversky (1979). Their research revealed that the choices made by individuals depend on the fact in which way the question is framed (Baker and Nofsinger, 2010).

\section{THEORETICAL FRAMEWORK OF LOGISTIC REGRESSION}

Regression analysis is a statistical method which aims to study the relationship between the independent variables (explanatory variables predictors) and the dependent variable. Formally, regression analysis allows to estimate the conditional expected value $\mathrm{E}(Y \mid X)$ of the dependent variable for specific values or a vector of independent variables. In practice, this method involves building a function to describe how the expected value of the dependent variable depends on the independent variables. The general form of the regression function can be summarized as follows:

$$
\mathrm{E}(X \mid Y)=f(X, \beta),
$$


where: $Y$ - dependent variable, $X$ - independent variable, $\mathrm{E}(X \mid Y)$ - the conditional expected value of $Y$ at a given value of $X, \beta$ - vector of regression coefficients, $f(X, \beta)$ - regression function.

In research practice there are situations where the dependent variable takes the value of 0 - when the phenomenon does not occur, or 1 - when the phenomenon (e.g. a specific behaviour, a disclosure of attitudes, opinions, etc.) occurs. This dichotomous nature of the dependent variable means that nonlinear analysis should be used. The regression model used for this type of dependent variables is logistic regression (logit model), in this case a binomial one. This has been used in research since the 1970s, namely since the publication of D. J. Finney's work entitled Probit analysis (1971).

The logistic regression model is based on the logistic function. It takes values from the $[0 ; 1]$ interval, where 0 and 1 are marginal values achieved in $+\infty$ and $-\infty$ (Hosmer and Lemeshow, 2000). The logistic regression equation, just like the linear regression equation, allows the calculation of the expected value of the dependent variable. As the logistic regression model involves binary dependent variables, the predicted value of the $Y^{\prime}$ dependent variable is replaced by the value of the conditional probability that the $Y$ dependent variable will take the value of 1 for the predictors $X_{1}$, $X_{2}, \ldots, X_{\mathrm{k}}$. The logistic function properties result in the fact that both of these values (the expected value of $Y^{\prime}$ and the conditional probability taking the value of 1) are equal. Thus, a logistic regression model can be expressed by the equation (Kleinbaum and Klein, 2005):

$$
\begin{gathered}
P\left(Y^{\prime}=1 \mid X_{1}, X_{2}, \ldots, X_{k}\right)=\frac{1}{1+e^{\operatorname{logit}(p)}}, \\
\operatorname{logit}(p)=\ln \frac{p}{1-p}=\ln (p)-\ln (1-p)=\beta_{0}+\beta_{1} X_{1}+\ldots+\beta_{k} X_{k},
\end{gathered}
$$

where: $P\left(Y^{\prime}=1 \mid X_{1}, X_{2}, \ldots, X_{k}\right)-$ the conditional probability of the dependent variable taking the value of 1 for specific values of the variables $X_{1}, X_{2}, \ldots, X_{\mathrm{k}} ; \beta_{0}$ - the logistic regression constant; $\beta_{\mathrm{i}}-$ the logistic regression coefficient for the $i^{\text {th }}$ predictor; $X_{\mathrm{i}}-$ the $i^{\text {th }}$ predictor; $i=1,2, \ldots, k$.

Logistic regression is based on the so-called odds $(\mathrm{O})$, i.e. the relative probability $p$ that an event will occur against the probability that it will not $(q=1-p)$. It is worth noting that the logistic regression coefficients are 
calculated by the maximum likelihood method, unlike the linear regression which employs the least squares method.

The logistic regression model is tested across three areas. The first one is testing the validity of the entire theory, which means the sum total of all the hypotheses. This boils down to examining the goodness-of-fit of the model, that is, answering the question of the extent to which it explains the dependent variable properly. The second area is the testing of individual hypotheses, which involves identifying the statistical significance of the impact made by the predictors on the dependent variable. The third dimension of verification is the analysis of the theory's predictive power, which means the identification of how efficiently the model classifies observations.

Verification of the goodness-of-fit of a model (theory) involves performing four tests to check collinearity, the likelihood ratio, the HosmerLemeshow test (goodness-of-fit test; for more details see Hosmer and Lemeshow,1980) and convergence. With the latter test, it should be noted that due to the method used for estimating the logistic regression coefficients, it also involved the determination coefficient known as pseudo$R^{2}$ (often referred to as McFadden's $R^{2}$ after its creator (McFadden, 1974), or rather its modified version - Nagelkerke's pseudo- $R^{2}$.

Upon completion of the goodness-of-fit model analysis, it is possible to start verifying the various hypotheses. For this purpose, logistic regression uses two methods, the Wald test $\left(Z_{w}\right)$ and the odds ratio $(O R)$. The former examines the statistical significance of the predictor's impact on the dependent variable and consists in first estimating the regression coefficient $\beta$ and the standard error S.E. for the given independent variable $X$, and then on this basis performing a calculation of the Wald statistics (5), which has a chi-square distribution and therefore its value obtained for $X$ should be compared with the critical value read from the distribution tables for any given $\alpha$

$$
Z_{w}=\frac{\beta}{S \cdot E \cdot(\beta)} .
$$

On the other hand, the odds ratio demonstrates the changes in the probability of an event contained in the dependent variable (value of 1) with the independent variable growing by a single unit. The ratio is calculated as follows:

$$
O R=\frac{O(A)}{O(B)}=\frac{P(A)}{1-P(A)} / \frac{P(B)}{1-P(B)}
$$

where: $P(A)$ - the probability of event occurrence (value 1 of the dependent variable) in category $A$ of observations (value 1 of independent variable); 
$P(B)$ - the probability of event occurrence (value 1 of the dependent variable) in category $B$ of observations (value 0 of independent variable).

It is assumed that if:

- $O R>1$, then $X$ stimulates the event occurrence. Then the $O R$ shows how much the probability of occurrence of 1 in the dependent variable grows when the predictor value increases by a single unit;

- $O R<1$, then $X$ destimulates the event occurrence. Then the $O R$ shows how much the probability of occurrence of 1 in the dependent variable falls when the predictor value increases by a single unit;

- $O R=1$, then $\mathrm{X}$ does not affect the event occurrence.

In the analysis of the odds ratio, a confidence interval $(C I)$ is determined for each predictor. This is a numerical range, which with a 1- $\alpha$ probability predetermined by the investigator and referred to as the confidence level, will contain an unknown value of the population's estimated parameter.

The third dimension of verification is the analysis of the theory's predictive power which means identification of how efficiently the model classifies observations. Verification of the model's predictive capability means performing two tests based on the classification table and the ROC curve.

With logistic regression, the standard classification table is a $2 \times 2$ matrix which covers the decision classes as predicted by the model and as actually observed (Hosmer and Lemeshow, 2000). An important element of the analysis of the table is to determine the percentage values of three parameters: accuracy $(A C C)$, sensitivity $(C)$ and specificity $(S)$. The first one determines what percentage of observations are cases correctly classified, either positively or negatively, by the model, the second one shows the percentage of cases correctly and positively classified by the model among all the cases positively observed, while the third one, i.e. specificity, determines the percentage of cases correctly but negatively classified by the model among all the cases negatively observed. These indicators are calculated for the cut-off point of the predicted probability and indicate the extent to which the model correctly predicts the dependent variable values.

The Receiver Operating Characteristics (ROC) analysis consists in constructing a curve to illustrate the relationship between two classification criteria: sensitivity and specificity. If the curve coincides with the diagonal $(y=x)$, this means that the model does not contribute to the analysis, because the classifications performed by the model are as good as random decisions. The closer the curve is to the left quadrant of the graph, the better the results achieved with the model. A high level of sensitivity (close to 1) implies that the model correctly identifies cases, while a low value of 1-S proves that only few negative cases get classified as positive. 
However the most important interpretative characteristics of $R O C$ is the area beneath the curve, referred to as Area Under Curve (AUC). It takes values within the $[0,1]$ interval and indicates the model's classification performance. The higher the $A U C$ value, the better the model (Hosmer and Lemeshow, 2000).

\section{METHOD}

The nature of the problem determined the selection of variables for the econometric model. The dependent variable $Y$ (the person taking financial decisions performs mental accounting, where 1 =success, $0=$ failure) is dichotomous in nature. The candidates for explanatory variables were selected on the basis of general knowledge of personal and behavioural finance, as well as a review of previous studies on similar topics. To some extent the experience or intuition of the authors was also taken into account. At the next stage of the research, the collection of statistical data began. This task was carried out in cooperation with the Interactive Institute of Market Research (IIBR), which in January 2013 conducted a CAWI survey among 1,000 Poles. The survey sample structure was corrected with an analytical weight so that it matched the population structure of Polish Internet users. The invitation to participate was posted on the websites with a total monthly reach of 70 percent of them.

With the gender criterion taken into account, the structure of sample analysed was as follows: 64.1 percent were women and 35.9 percent - men. Figure 1 shows the division of respondents into five age groups.

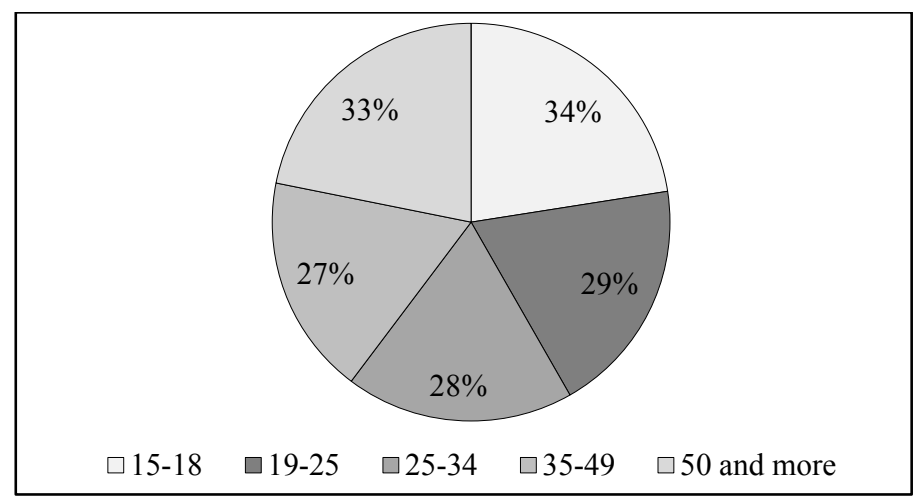

Fig. 1. Age structure of the respondent group.

Source: own study. 
People with tertiary education accounted for 33 percent of the sample studied, the share of those with secondary education was smaller by 3 percentage points and the other respondents declared to have only primary, junior secondary or semi-secondary vocational education. Figure 2 shows the structure of the same sample in terms of population of their place of residence.

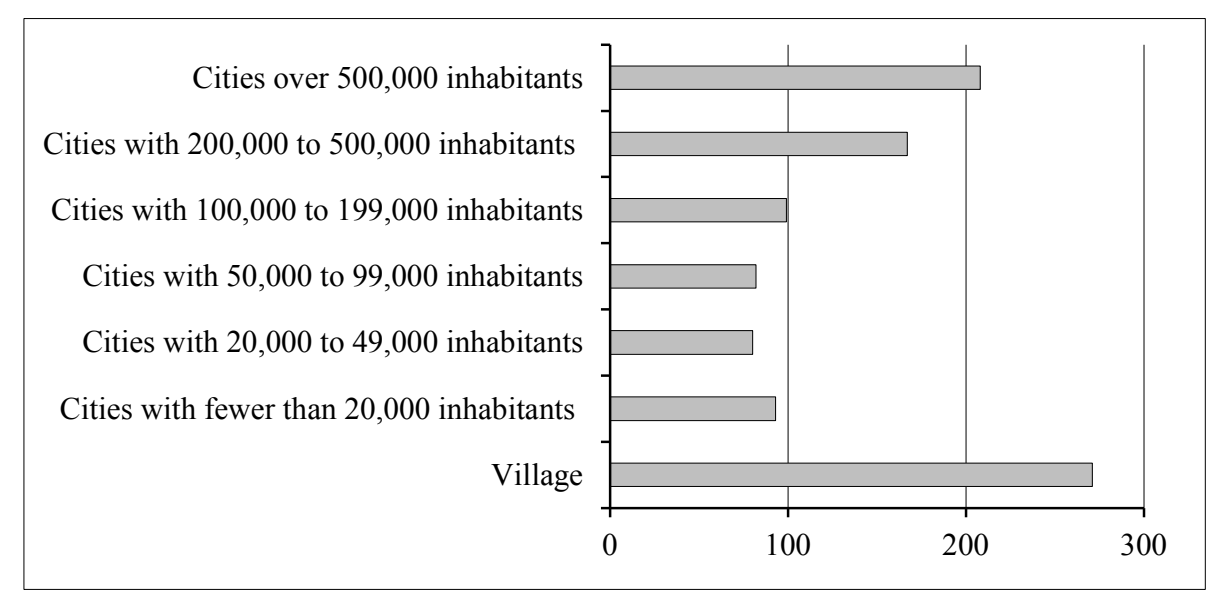

Fig. 2. The respondent group by population size of their place of residence.

Source: own study.

Approximately 8.7 percent of the population sample were single-person households. Respondents who declared that their household consisted of two persons constituted 24 percent of the total. A similar proportion of respondents (25.3 percent) lived in three-person households. The other respondents declared that their households were shared by four or more people.

The breakdown of the survey sample by income is presented in Figure 3. The largest percentage of respondents ( 40.7 percent) declared a monthly net income of their households as falling within the range of PLN 2,000-5,000. 


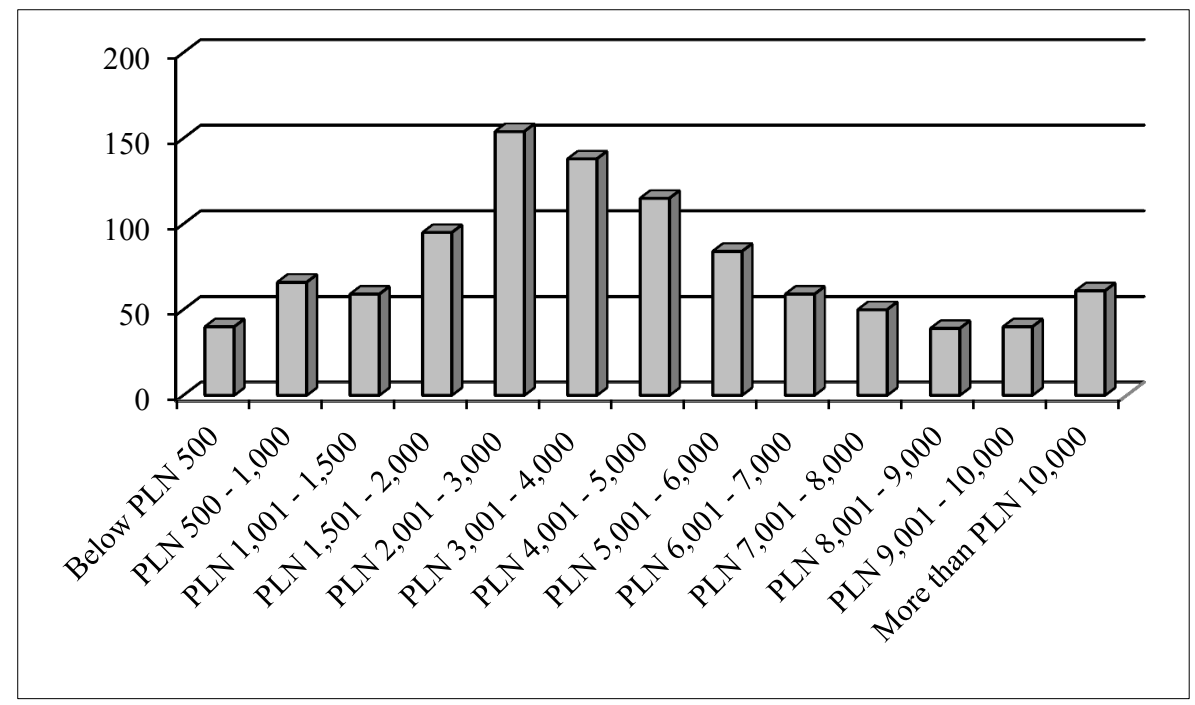

Fig. 3. The respondent group by net income of their households.

Source: own study.

The responses to two selected questions (Q1 and Q2) - see Figure 4 were used for coding the dependent variable $(Y)$. The first question $(\mathrm{Q} 1)$ was about the immediate necessity to purchase a car and required choosing between using the savings earmarked for a child's education or taking a loan (from various sources). The first option was selected by 48 percent of Polish Internet users aged 15+, which means that for these people, money is substitutable. For the remaining 52 percent of respondents, money is 'tagged', which means that they prefer borrowing money elsewhere to reducing the savings accumulated for a specific purpose. The second question (Q2) presented the situation of extremely favourable market conditions which made it profitable to overpay a foreign currency mortgage loan. The respondents had to decide whether to use the earmarked savings or to borrow money, always capitalizing on the favourable exchange rate. It turned out that the vast majority, namely about 80 percent, decided to use the savings, while only 20 percent decided to take a loan, thus joining the number of people who perform mental accounting.

A person who uses mental accounting for financial decisions $(Y)$ was defined as one whose response to at least one of the questions indicated that his/her savings are 'earmarked'. The sample was found to number 225 such persons. 
In this context, the research question was posed: What factors favour mental accounting? A dozen or so independent variables were selected for the analysis - their nature was either economic (income level, having savings or credit available), socio-demographic (gender, age, education level, size of locality lived in, career stage) or psychological (debt aversion a variable described below in more detail, prudence or impatience). A prudent person gives up current response consumption to secure the deferred one. The group of prudent people was created by including the respondents whose answers to questions (Q3) and (Q6) showed the intention to save money, avoiding being in debt - 61 percent (Q3) and 43 percent (Q6) of the responses. Question (Q3) describes the following hypothetical situation: "Imagine that your regular income is not sufficient to finance the necessary expenses associated with Christmas. What would you do in such a situation?" (see Table 2).

Table 2

Responses to question Q3

\begin{tabular}{l|c}
\hline \multicolumn{1}{c|}{$\begin{array}{c}\text { Imagine that your regular income is not sufficient to finance the } \\
\text { necessary expenses associated with Christmas. What would you } \\
\text { do in such a situation? }\end{array}$} & $\begin{array}{c}\text { Response } \\
\text { selected } \\
{[\%]}\end{array}$ \\
\hline start saving small amounts as early as right after summer holidays & $61 \%$ \\
\hline cover the extra expenses with my credit card & $17 \%$ \\
\hline borrow money from family/friends & $15 \%$ \\
\hline take a consumer credit & $3 \%$ \\
\hline use an offer of some lending institution, e.g. Provident & $4 \%$ \\
\hline
\end{tabular}

Source: own study.

Question (Q6) refers to a different case: "Five years ago you got married and currently you are expecting a child. You rent a studio and have saved PLN 30,000 towards buying your own home. There emerges a chance to buy an apartment at PLN 150,000. Assuming that you have a good credit standing, what would you do in such a situation?". Question (Q6) offers two possible variants: 1) "I'd continue saving in order to buy an apartment in the future because I do not want to have debts", and 2) "I'm going to buy a flat I'm going to use the saved money and take a mortgage loan to cover the missing amount". 


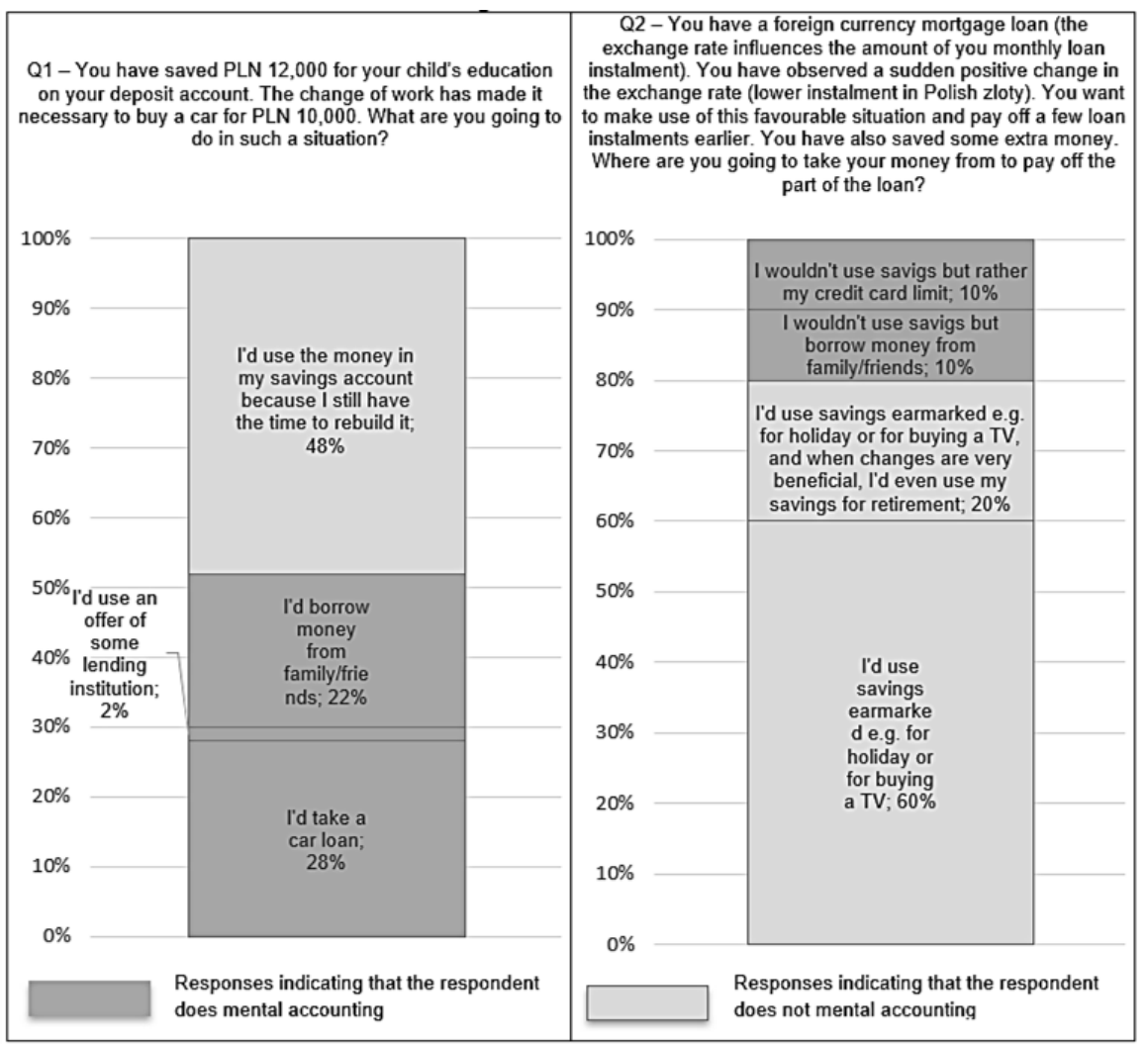

Fig. 4. Responses to questions Q1 and Q2 used to split the sample into groups of those who do and do not do mental accounting.

Source: own study.

People described as impatient prefer current consumption over deferred, and are not able to focus on the long-term effects of their decisions. This group was created by including the respondents whose response to questions (Q4) and (Q5) - on the use of unexpected cash windfalls (respectively: a bonus and a lottery win) - was that they would apply the windfall to current consumption (13 percent in Q4 and 20 percent in Q5); see Table 3.

After calculating the degree of variability (variability coefficient $V_{x}$ was above $30 \%$ ), we proceeded to the selection of candidate repressors. Finally, four variables (see Table 4) were selected for further research as they proved to be most strongly related to the dependent variable $Y$ and at the same time the least related to each other. The significance of correlation was tested by means of Yule's Q, Phi, Pearson's C and Cramer's V methods. 
Table 3

Responses to questions Q4 and Q5

\begin{tabular}{l|c|l|c}
\hline $\begin{array}{c}\text { Your employer has paid you a } \\
\text { bonus of PLN 5,000. You're } \\
\text { repaying a consumer credit } \\
\text { and still have PLN 7,000 to } \\
\text { repay. How will you use the } \\
\text { bonus? (Q4) }\end{array}$ & $\begin{array}{c}\text { Response } \\
\text { selected } \\
{[\%]}\end{array}$ & $\begin{array}{c}\text { You have won PLN 10,000 in a } \\
\text { lottery. You're paying off a } \\
\text { mortgage. Currently you still } \\
\text { have PLN 150,000 to repay. } \\
\text { What will you do with the } \\
\text { money won? (Q5) }\end{array}$ & $\begin{array}{c}\text { Response } \\
\text { selected } \\
{[\%]}\end{array}$ \\
\hline $\begin{array}{l}\text { put it towards repaying the } \\
\text { credit }\end{array}$ & $74 \%$ & $\begin{array}{l}\text { put the winnings towards } \\
\text { repaying the mortgage }\end{array}$ & $55 \%$ \\
\hline $\begin{array}{l}\text { save it for holidays, car } \\
\text { replacement or another major } \\
\text { expense }\end{array}$ & $12 \%$ & $\begin{array}{l}\text { put the winnings to a savings } \\
\text { account in view of future } \\
\text { expenses, e.g. for holidays or car } \\
\text { replacement }\end{array}$ & $23 \%$ \\
\hline put it towards my pension plan & $1 \%$ & $\begin{array}{l}\text { save the winnings for my } \\
\text { retirement }\end{array}$ & $2 \%$ \\
\hline use it for current expenses & $13 \%$ & $\begin{array}{l}\text { use the winnings for current } \\
\text { expenses }\end{array}$ & $20 \%$ \\
\hline
\end{tabular}

Source: own study.

Table 4

Independent variables used in the logistic model

\begin{tabular}{|c|c|}
\hline Variable & Specification \\
\hline$X_{1}-$ having savings & $\begin{array}{l}\text { Parametric binary variable }(1-\text { person having savings; } 0-\text { person } \\
\text { without savings) }\end{array}$ \\
\hline$X_{2}-$ debt & $\begin{array}{l}\text { Ordinal nonparametric multicategory variable ( } 3 \text { - person with a very } \\
\text { strong aversion to debt; } 2 \text { - person with a strong aversion to debt; } 1 \text { - } \\
\text { person with a weak aversion to debt; } 0 \text { - person with no aversion to debt) }\end{array}$ \\
\hline $\begin{array}{l}X_{3} \quad-\text { having a } \\
\text { credit/loan }\end{array}$ & $\begin{array}{l}\text { Nonparametric binary variable }(1-\text { person having a credit/loan; } 0- \\
\text { person without credit/loan) }\end{array}$ \\
\hline $\begin{array}{l}X_{4}-\text { monthly net } \\
\text { income }\end{array}$ & $\begin{array}{l}\text { Interval nonparametric multicategory variable (from category } 1 \text { for the } \\
<\text { PLN } 500 \text { interval to category } 13 \text { for the } \geq P L N ~ 10,000 \text { interval) }\end{array}$ \\
\hline
\end{tabular}

Source: own study.

Within the population analysed, 70 percent of respondents declared to have savings (variable $X_{1}$ ). The other regressor selected $\left(X_{2}\right)$ requires a comment here. Debt aversion was coded on the basis of the answers provided by the respondents to three questions. The first of these questions (Q3) was: "Imagine that your regular income is not sufficient to finance the necessary expenses associated with Christmas. What would you do in such a situation?" and was intended to identify people with debt aversion (61 percent of responses) - see Table 2. The responses to the two following 
questions, $\mathrm{O} 4$ and $\mathrm{Q} 5$, in which the respondents were to decide what to do with a cash windfall (bonus and lottery prize, respectively) - whether to use the money to repay a debt, save/invest it or spend it on everyday needs, are presented in Table 3. Those who chose the first option (74 percent of respondents in Q4, and 55 percent in Q5) can be presumed to be psychologically stressed by any credit, which they associate with discomfort and want to repay as soon as possible. The respondents who made such a choice can be described as showing an aversion to debt (see Thaler, 2012).

A person showing a very strong aversion to debt is a person whose responses to all the three questions demonstrated their aversion to debt. A person showing a strong aversion to debt was assumed to be a person who demonstrated such an attitude in two out of the three questions, while a person with weak aversion to debt was defined as a respondent whose single response indicated aversion to debt.

In the population surveyed, the percentage of people with a loan/credit to repay (variable $X_{3}$ ) was 50 percent. Variable $X_{4}$ - the amount of monthly net income - was presented in detail in the description of the survey sample.

The next stage of constructing the logistic regression model is the formulation of research hypotheses related to the impact of individual factors (independent variables) on mental accounting (dependent variable). The investigation conducted by Thaler (1990) shows that the idea of mental accounting is related to the creation of the following types of mental accounts: $I, A$ and $F$ (current income, asset and future income). The expenses exceeding current income $(I)$ will result in an aversion to using the funds kept in the $A$ and $F$ mental accounts. On this basis we can suppose that these individuals will not be characterised by strong debt aversion (they prefer to take a loan rather than touch their savings). Taking decisions which is characteristic for individuals using mental accounts may thus explain the fact that they have already had credits/loans (taken before) as well as savings (accumulated before). The amount of monthly net income constitutes a factor affecting both creditworthiness and the possibility to accumulate savings. Thus, we have:

$\mathrm{H}_{1}$ : Mental accounting is more likely to occur in people with savings;

$\mathrm{H}_{2}$ : Mental accounting is more likely to occur in people with debt aversion;

$\mathrm{H}_{3}$ : Mental accounting is more likely to occur in people with credits/loans;

$\mathrm{H}_{4}$ : Mental accounting is more likely to occur in people with a higher monthly net income. 
Then we need to formulate the null hypotheses, which oppose the ones above. They assume the lack of any significant impact of respectively $\mathrm{X} 1$, $\mathrm{X} 2, \mathrm{X} 3$, and $\mathrm{X} 4$ on $\mathrm{Y}-$ mental accounting.

\section{RESULTS}

Upon entering data into equation (3), we arrive at the following logistic regression model (7) which at the next stage will be verified in three areas: goodness-of-fit of the model, significance of each of the hypotheses and the theory's predictive power

$$
P\left(Y^{\prime}=1 \mid X_{1}, X_{2}, X_{3}, X_{4}\right)=\frac{1}{1+e^{-\left(b_{0}+b_{1} X_{1}+b_{2} X_{2}+b_{3} X_{3}+b_{4} X_{4}\right)}} .
$$

Starting from the first area, a collinearity test should be performed first. The cross-correlations between predictors, including the intercept, are strongly indicative of poor correlation and never exceed the limit of 0.1. In addition, for all the variables, the VIF coefficient stays below the critical value $(V I F<3)$. Therefore, the undesirable collinearity can be excluded.

The results of the three consecutive tests of the model's goodness-of-fit are shown in Table 5. As regards the value of $G$ statistics for the model's deviance, it is 206.83 while the $X_{\text {critical }}^{2}$ for $\alpha=0.01$ and for four degrees of freedom is equal to 13.277 , which means that the test result is statistically significant. Therefore $\mathrm{H}_{0}$ can be rejected and it seems safe to assume that the model is far better than random. The second test - Hosmer-Lemeshow - also confirms the good fit of the model, because it is not significant at the level of 0.01, as the $X_{\text {critical }}^{2}$ for $\alpha$ and for eight degrees of freedom is equal to 20.09 and in this case $X_{\text {calculated }}^{2}<X_{\text {critical }}^{2}(5.85<20.09)$ for $p>\alpha(0.67>0.01)$. On the other hand, Nagelkerke's pseudo- $\mathrm{R}^{2}$ determination coefficient shows that 25 percent of the variance of the dependent variable is explained by the variance of independent variables. This means that there is still a large percentage of variance which is explained by other predictors, not included in the model. However, as shown above, the value of pseudo- $R^{2}$ in logistic regression is usually not high, hence the above result can be considered satisfactory. Generally, the model has passed the goodness-of-fit test as it proved better than the random model and it gives a new explanation of the dependent variable's behaviour.

Upon completion of the goodness-of-fit model analysis it is possible to start testing the various hypotheses. Table 6 presents the regression coefficients, standard errors, Wald statistic results, odds ratios and confidence intervals. 
Table 5

The model's goodness-of-fit coefficients

\begin{tabular}{c|c|c}
\hline Test & Coefficient \\
\hline Likelihood ratio test & $-2 \log (L)=1162$ & $\chi^{2}=206.83(\mathrm{~d} f=4 ; p=<0.000001)$ \\
\hline Hosmer-Lemenshow test & \multicolumn{2}{|c}{$\chi^{2}=5.83(\mathrm{df}=8 ; p=0.666)$} \\
\hline$R^{2}$ Nagelkerke & 0.25 \\
\hline
\end{tabular}

Source: own study using the PQStat Statistical Computing Software.

Table 6

Logistic regression results

\begin{tabular}{l|c|c|c|c|c|c|c|c|c}
\hline $\begin{array}{c}\text { Specifi- } \\
\text { cation }\end{array}$ & $\begin{array}{c}\text { coefficient } \\
\boldsymbol{b}\end{array}$ & $\boldsymbol{b}$ error & $\mathbf{- 9 9 \%} \boldsymbol{C I}$ & $\mathbf{+ 9 9 \%} \boldsymbol{C I}$ & $\begin{array}{c}\text { Wald } \\
\text { statistic }\end{array}$ & $\boldsymbol{p}$-value & odds ratio & $\mathbf{- 9 9 \%} \boldsymbol{C I}$ & $\mathbf{+ 9 9 \%} \boldsymbol{C I}$ \\
\hline intercept & 1.324204 & 0.269685 & 0.629541 & 2.018866 & 24.10993 & 0.000001 & 3.759191 & 1.876749 & 7.529784 \\
\hline$X_{1}$ & -1.55862 & 0.184139 & -2.03293 & -1.08431 & 71.64653 & $<0.000001$ & 0.210424 & 0.13095 & 0.338132 \\
\hline$X_{2}$ & -0.51908 & 0.079644 & -0.72423 & -0.31393 & 42.47891 & $<0.000001$ & 0.595064 & 0.484695 & 0.730565 \\
\hline$X_{3}$ & 0.85970 & 0.143824 & 0.489235 & 1.230165 & 35.73008 & $<0.000001$ & 2.362452 & 1.631068 & 3.421795 \\
\hline$X_{4}$ & 0.103871 & 0.028887 & 0.029463 & 0.178279 & 12.92699 & 0.000323 & 1.109457 & 1.029902 & 1.195159 \\
\hline
\end{tabular}

Source: own study using the PQStat Statistical Computing Software.

The logistic regression equation takes the following form:

$$
\begin{aligned}
& P\left(Y^{\prime}=1 \mid X_{1}, X_{2}, X_{3}, X_{4}\right)= \\
& \frac{1}{1+e^{-\left(1,324204-1,55862 X_{1} 0,51908 X_{2}+0,8597 X_{3}+0,103871 X_{4}\right)}} .
\end{aligned}
$$

The $X_{1}$ variable is statistically highly significant $(\mathrm{p}<0.000001)$, which allows the rejection of $\mathrm{H}_{0}$ about the zero impact of the predictor on the dependent variable and accepting the alternative $\mathrm{H}_{1}$ hypothesis as true ( $X_{\text {critical }}^{2}$ for $\alpha=0.01$ and $d f=1$ is 6.635 , while the Wald statistic value for the model is 71.647). The $O R$ for the analyzed variable is 0.21 (see Figure 5 ), i.e. less than 1 , which proves the destimulating and negative impact of having savings on mental accounting. This value can be interpreted as follows: the probability of mental accounting occurring in people with savings is nearly five times smaller than the probability of mental accounting occurring in people who have no savings. The confidence intervals of this variable indicate that with the probability of 0.99 it can be expected that the $O R$ for mental accounting occurring with having savings will be not be lower than 0.131 and not higher than 0.338 . 
The next variable, $X_{2}$ is also highly significant statistically ( $<<0.000001$ ), which allows the rejection of $\mathrm{H}_{0}$ about the zero impact of the predictor on the dependent variable and accepting the alternative $\mathrm{H}_{2}$ hypothesis as true ( $X_{\text {critical }}^{2}$ for $\alpha=0.01$ and $d f=1$ is 6.635 , while the Wald statistic value in this case is 42.479). The $O R$ for the $X_{2}$ is 0.60 , i.e. less than 1 , which proves the destimulating and negative impact of debt aversion on mental accounting. This means that people who are afraid to get into debt and thus avoid credit/loans are less vulnerable on mental accounting. This $O R$ value can be interpreted as follows: the probability of mental accounting occurring with a given person decreases 1.5 -fold with each increase in debt aversion by a single level. The $C I$ of this variable ranges from 0.486 to 0.731 .

Just like the two aforementioned explanatory variables, $X_{3}$ is statistically highly significant $(\mathrm{p}<0.000001)$, which allows the rejection of $\mathrm{H}_{0}$ about the zero impact of the predictor on the dependent variable and accepting the alternative $\mathrm{H}_{3}$ hypothesis as true ( $X_{\text {critical }}^{2}$ for $\alpha=0.01$ and $d f=1$ is 6.635 , while the Wald statistic value for this predictor is 35.731). The $O R$ for the analyzed variable is 2.36 , i.e. more than 1 , which proves the stimulating and positive impact of having a credit/loan on mental accounting. This value can be interpreted as follows: the probability of mental accounting occurring among people with credits/loans is nearly 2.5 times higher than in people who do not have loans. The $C I$ of this variable indicates that with the probability of 0.99 it can be expected that the $O R$ for mental accounting occurring with extant debt will not be lower than 1.631 and not higher than 3.422.

The last independent variable analysed, $X_{4}$, is statistically highly significant as $\mathrm{p}$ is below $\alpha=0.01$, which allows the rejection of $\mathrm{H}_{0}$ about the zero impact of the predictor on the dependent variable and accepting the alternative $\mathrm{H}_{4}$ hypothesis as true ( $X_{\text {critical }}^{2}$ for $\alpha=0.01$ and $d f=1$ is 6.635 , while the Wald statistic value is 12.927). The $O R$ for this variable is 1.11, i.e. slightly more than 1 , which proves the stimulating and positive, albeit modest impact of the predictor on mental accounting. This means that people with higher incomes are more prone to mental accounting. The $O R$ value can be interpreted as follows: the transition of a given person to a higher income group increases the likelihood of mental accounting occurring by about 0.11 times. The $\mathrm{CI}$ of the $\mathrm{X}_{4}$ is between 1.030 and 1.195 .

Upon completion of the hypotheses testing, the next step is testing the model's predictive power. Table 7 illustrates the theory's capacity for classification. The model's accuracy $(A C C)$ with a cut-off point of 0.49 is $75.6 \%([(435+269) / 1000] \cdot 100 \%)$ and is higher when compared to a 
model with only an intercept, which means that the resulting model has some added value. The other parameters of the model, i.e. its sensitivity and specificity, reach the respective values of $C=76.86 \%([435 / 566] \cdot 100 \%)$ and $S=61.98 \%([269 / 434] \cdot 100 \%)$.

Table 7

Classification

\begin{tabular}{|c|c|c|c|c|}
\hline \multirow{2}{*}{\multicolumn{2}{|c|}{ Classification }} & \multicolumn{3}{|c|}{ Observed value } \\
\hline & & 1 (positive) & 0 (negative) & $\Sigma$ \\
\hline \multirow{3}{*}{$\begin{array}{l}\text { Predicted } \\
\text { value }\end{array}$} & 1 (positive) & 435 & 165 & 600 \\
\hline & 0 (negative) & 131 & 269 & 400 \\
\hline & $\Sigma$ & 566 & 434 & 1000 \\
\hline
\end{tabular}

Source: own work using the PQStat Statistical Computing Software.

The model was correct at classifying about 75 percent of decision categories, of which 77 percent of the positive and 62 percent of the negative cases were correctly grouped. It seems, therefore, that while the theory is very capable of predicting the adoption of mental accounting attitude, it is worse at predicting the behaviour of people who do not demonstrate the attitudes associated with mental accounting. In this context, the positive predictive value of the model is lower.



Fig. 5. Odds Ratio.

Source: own study using the PQStat Statistical Computing Software.
Fig. 6. ROC curve.

Source: own work using the PQStat Statistical Computing Software. 
The model's sensitivity and specificity were instrumental in constructing the ROC curve (Figure 6). The area under the curve (AUC) is 0.756 with $p<0.000001$ (more than 0.5) and thus the model is acceptable and classifies cases much better than the model based on random guessing.

To sum up, these considerations indicate that mental accounting is more likely in people who have neither savings nor aversion to debt, have taken a loan/credit and achieve higher monthly net incomes.

\section{DISCUSSION OF THE RESULTS}

Savings and credit decisions combining the area of savings and credit were not previously the subject of empirical research in the context of mental accounting. Analysing the results of the conducted investigation, it is necessary to pay attention to the fact that among the most crucial characteristics of the individuals adopting the attitude of mental accounting there are having loans/credits, having savings, aversion to debt and the level of income. The first characteristic of a person adopting the attitude of mental accounting is having a loan. It can be assumed that when put in a hypothetical decision situation that requires the choice between purchasing a car from savings or from credit (Q1), a person holding an actual loan will not want to increase their credit exposure. The study shows, however, that having a real loan promotes mental accounting. It turned out that the proportion of people with loans in the group of mentally accounting respondents was higher by 24 percent than in the entire sample. This can be explained by the fact that in such a situation the psychological preferences of respondents prevail while the economic factors recede into the background. Making the decision to take the loan is not therefore strictly related to the need to assess the current credit worthiness or the future ability to service such a debt. The investigation conducted in this article enabled the authors to confirm the formulated hypothesis which says that individuals characterised by debt aversion do not show an inclination to adopt the attitude of mental accounting in a wider sense.

In addition, it should be noted that 22 percent of people who do mental accounting have actual loans but no savings. This may indicate that they are characterised by greed and myopia, in line with the concept that all financial decisions are made somewhere in between greed and fear (Kleinbaum and Klein, 2005). In every decision-making situation involving savings and loans they will prefer loans. 
For question Q2 we analyzed the preferences of people who have actually incurred a debt and were put in the hypothetical situation of having a mortgage denominated in a foreign currency. These are people who know from their own experience the pain associated with the need to pay debt instalments. In the context of an opportunity for overpayment of the debt in favourable market conditions, for many (41 percent) of the respondents this experience translates into the decision to use their savings. The reluctance to incur further debt in this situation was due to its goal - to reduce the original debt (see Loewenstein and Thaler, 1989). Meanwhile, persons adopting the attitude of mental accounting tend to protect savings, and thus prefer to increase their debt. It seems that these people who actually are in debt may perceive savings as a sort of safety buffer.

Another feature which influences significantly adopting the attitudes associated with mental accounting is having savings. First, it should be noted that the debt decisions are not without influence on the ability to save in future periods. In line with the aforementioned Thaler's observation, spending money from the $A$ and $F$ accounts is more painful than from the $I$ account. It is worth noting that the financial decisions may involve situations in which decisions made within a given period (e.g. a month) affect the future expenditure from the $I$ account. This gives rise to a peculiar decision knot, in which individuals choose between reducing the $A$ account and using funds in the $I$ account related to future periods. These are the decisions in which the amount of current budget expenditure (e.g. the purchase value of some goods) exceeds the $I$ amount; therefore, such decisions are creditrelated in nature. The amount of necessary debt service will remain a burden to the household budget for $n$ consecutive periods. As a result, the total amount of payable $(M)$ divided by $n$ periods produces the amount of $m$, which for $n$ periods will steadily affect the expenditure allocated to current consumption. This situation can be expressed as follows:

$$
\begin{gathered}
t_{0} \rightarrow I_{0}+A_{0}+F_{0} \\
t_{l} \rightarrow\left[\left(I_{1}-m\right)+D\right]+A_{1}+F_{l} \\
t_{n} \rightarrow\left[\left(I_{n}-m\right)\right]+A_{n}+F_{n}
\end{gathered}
$$

where: $D$ - the total amount of credit; $m$-the amount of debt service attributable to a specific period (instalments of principal and interest, plus other costs such as fees or insurance premiums); $n$-number of periods of debt repayment; $\left(I_{n}-m\right)$ - current income, less the savings rate earmarked for future income (e.g. retirement), remaining at the household's disposal 
after repayment of the debt amount attributable to a specific period. Additional assumptions are: all the instalment amounts are equal (no grace period), the total amount of payable $(M)$ is always repaid from the mental $I$ account, the total amount of credit $(D)$ increased the funds accumulated in the mental $I$ account and was used to purchase given goods/services in the first period.

While for $n$ successive periods the $m$ amount remains strictly linked to current consumption, the amount of a household's disposable income $\left(I_{n}-m\right)$ may be used either for current consumption or to increase the $A$ and/or $F$ account. Hence the funds accumulated in the assets account and/or future income at baseline $\left(A_{0} / F_{0}\right)$ may during any subsequent period be larger, smaller or the same. While assuming a constant value of $I$ for all $n$ periods, it must be remembered that a loan-taking decision will have a direct impact on the ability to save, i.e. to top up the $A$ and $F$ accounts.

Surprisingly, the study results show that having savings in real life does not promote mental accounting. It turned out that in the group of respondents who did mental accounting, the proportion of people with savings was smaller by $15 \%$ than in the entire sample. In such a situation, it is worth considering why the people who do not have savings do mental accounting. The adoption of such an attitude may be justified by the strongly felt need to accumulate savings so as to fulfil the need for safety. Thus, the respondents who are put in a situation of having to choose whether they will finance the purchase of specific goods with the hypothetically owned savings or with a loan (Q1), prefer the latter option. Having no accumulated savings need not be synonymous with a lack of propensity to save. This may also be a derivative of certain factors of a socio-economic nature, such as low household income or the number of dependent children.

In the group of mentally accounting people, 37 percent had no savings while more than half of them demonstrated the propensity to save. This feature has been assigned to people who, when asked about their way to finance the necessary expenses for Christmas (Q3), chose the early accumulation of savings out of the five available options (the other four involving debt).

The third feature in terms of the power to stimulate the adoption of attitudes related to mental accounting is debt aversion. When faced with a choice how to finance buying a car, people who do mental accounting and have accumulated savings to finance a child's education will tend to preserve the accumulated funds and thus they feel the necessity of borrowing. Debt aversion is coupled with a systematic interference between the pleasures 
derived from consumption and the size and timing of payments (Prelec and Loewenstein, 1998).

This psychological trait is derived from a different perception of the risks associated with debt repayment. When comparing the attitudes of two people in the same economic situation, differences in the level of reported concerns about the future become visible. The lower the level of concern, the more easily a credit decision is made. Debt aversion may:

- appear to be a dominant personality trait - fear determines any and all decisions,

- occur as a result of socialization, through observation of parents' behaviour,

- result from own negative experience.

Thus, aversion to debt will result in the avoidance of any option that involves the creation of debt or the reduction of any extant debt. The degree of respondents' debt aversion was rated on the basis of their responses to three additional questions. The first of these questions (Q3) concerned the choice of method to finance the necessary expenses associated with Christmas. A person characterized by debt aversion will avoid creating any debt (credit card, consumer credit, lending institution, family/friends), opting instead for the early accumulation of small amounts of money. The other questions (Q4, Q5) were related to the reduction of the already existing hypothetical debt, for instance with the use of funds which constitute windfalls (lottery winnings and bonus). People with debt aversion used the additional funds to repay debt. The analysis showed that within the mental accounting group the proportion of persons with a strong and very strong debt aversion was higher by 20 percent than in the entire sample.

The research clearly shows that both in the question about buying a car (Q1) and in the question about overpaying a foreign currency mortgage loan in favourable market conditions (Q2), people with no aversion to debt opted for a loan, and thus did not reduce their savings. Thus a lack of debt aversion fosters an attitude of mental accounting.

The attitude of mental accounting is stimulated by the higher income levels which were the last of the features analyzed. When faced with credit and savings decisions, people with high incomes demonstrate a higher propensity to debt. An analysis of the study results confirmed the dependence that a higher level of income makes the decision to incur debt easier - in the context of both economic and psychological considerations. With regard to the questions posed to respondents, it should be noted that a person with high level of current income will not need to reduce the 
savings, as in both analyzed cases they will be readily able to service the debt incurred.

The average monthly net salary for the entire sample was about PLN 3,000 or $€ 714.30$ at the official exchange rate of 26 September 2013, while nationally, in the second quarter of 2013 it was approximately PLN 2,400 or $€ 571.43$ at the same rate (The average..., 2017). Delineation of the third quartile allowed to identify the range of high incomes (over PLN 5,000 monthly). It turns out that within this range the number of those doing mental accounting is much higher (over 30 percent of the sample) than in the remaining population ( 20 percent of the sample). This proves that the size of income generated is conducive to the attitude of mental accounting. People with lower incomes will, in turn, tend to use their savings, with the result that the money accumulated in the various mental accounts will have a higher degree of substitutability. It should be noted, however, that where the capital was being accumulated over a longer period, and the savings use date is not too distant, people with lower income may be afraid to reduce these savings as they will be hard to rebuild.

A more detailed analysis of the results revealed that the factors determining individual choices in situations involving savings and credit decisions include the objective of consumer spending as well as the time horizon and the purpose of saving.

In order to examine the former factor in full detail, question Q1 made the respondents face the necessity of buying a car, while Q2 - an opportunity of overpaying a mortgage denominated in a foreign currency, thanks to a favourable situation in the currency market. The difference between the two hypothetical situations is that the former involves a forced move, while the latter - a voluntary one. In the decision-making situation related to a car purchase, 48 percent of the respondents chose to retain the savings and take a loan, while with credit overpayment that attitude was adopted by only 20 percent of the respondents. Since discounting the favourable situation on the currency market was not seen as necessary, in these circumstances people seem reluctant to incur debt. It follows clearly that the necessity of expenditure has a significant impact on the decisions taken.

The difference of consumption objectives translated into the significant difference in the numbers of people taking the mental accounting attitude in questions Q1 and Q2. This correlation explains why so few respondents (only 12 percent) adopted the attitude of mental accounting in both questions.

The diversity of behaviour is also determined by the different time horizons of saving. As previous research had demonstrated, "people divide 
their wealth into fixed accounts and interim accounts on the basis of their saving goals, and generally do not transfer money from the fixed account in order to meet temporary consumption demands" (Gou et al., 2013, p. 626). The results of our study show that in question Q2 long-term retirement savings were used only by 20 percent of respondents. This confirms the assumption that long-term savings are not used to satisfy current needs.

The situation presented in question Q2 also allows the conclusion on the significance of the purpose of saving, since only 20 percent of the respondents used their retirement savings while 60 percent used their earmarked savings (e.g. for a TV purchase or for holidays). The higher the goal of saving, in terms of Maslow's hierarchy of needs, the higher the level of money non-fungibility.

\section{CONCLUSIONS AND DIRECTIONS FOR FUTURE RESEARCH}

The subject of discussion in this article refers to the financial decisions of a particular type, namely, savings and credit decisions. Their characteristics include the fact that they always lead to achieving the intended purpose, but they differ in the manner of achieving it. A respondent faced with a hypothetical decision must choose one of the two options - savings or debt management.

As a result of the study, a large set of factors of a demographic, economic, social and psychological nature was researched to select a set of features favouring the attitude of mental accounting in a wider interpretation. A logistic regression model was built to analyse the strength and direction of their impact on the respondents' propensity to the examined attitude. The study shows that among the identified features, which to the greatest extent favour the attitude of mental accounting in a wider sense there are: having debt, having savings, debt aversion and the amount of monthly net income achieved. Both having debt and high monthly net income increase the likelihood of adopting mental accounting, while the other factors have the opposite effect. In addition to the above factors, the behaviour of the people likely to do mental accounting is also affected by the objective of consumer spending as well as the time and the purpose of saving.

An analysis of the economic costs and benefits shows that the behaviour of people practicing mental accounting should not be classified as rational or irrational. With question Q1, the decision of a person who did not opt to terminate a term deposit should be regarded as economically unjustified. The average annual interest rate on bank deposits fluctuates at around $4.5 \%$ p.a. 
as of January 2013, while the average real interest rate on car loans (interest including additional costs such as commission or premium) is $16.5 \%$ p.a. and on loans offered by lending institutions, such as Provident - roughly $86 \%$.

The decision to incur debt, although unprofitable from the financial perspective, can be justified through the observation that for many individuals the benefits of meeting the need for safety (care for their family, in this case for the child's education) somehow outweigh the financial costs. Depending on individual preferences, either economic or psychological benefits may be perceived as more important, which proves the importance of the psychological factors of financial decision-making.

On the other hand, an analysis of respondents' answers to question Q3 shows that the behaviour of mentally accounting individuals may prove an economically justified choice. A person who decided to borrow money from family/friends, and use the debt limit on a credit card may avoid the cost of debt servicing. It thus appears that, in relation to the options presented, satisfying the need for safety (psychological aspect) favours a financially favourable decision (economic aspect).

The adoption of the attitude of mental accounting carries both advantages and disadvantages. The former include mainly the fact that the attitude builds the ability to systematically manage the household budget, allows for the efficient planning of income and expenditure as well as consistently sticking to the previous decisions. Creating mental accounts facilitates the organization of personal finances which promotes achieving the goals of saving. This is so because self-control plays a vital role in effective budget management. An implication of a lack of self-control is that individuals will prefer regular contribution schemes where they are "locked-in" (Booth et al., 2000). In addition, the use of mental accounts restricts the allocation of some types of income for specific consumption, e.g. savings earmarked for retirement may not be used for current consumption (Graham and Isaac, 2002). Another advantage is the ability to meet the need for security, which translates into an opportunity to prevent the negative consequences of possible future events (a lower quality of life after retirement or a sudden illness).

With regard to the disadvantages of adopting the said attitude, it should be emphasised that the decision to protect savings, which results in the need for indebtedness, exposes the individual to the risks of debt service and extra costs. The study results demonstrated that a person who does mental accounting shows no debt aversion and thus becomes susceptible to the risks 
associated with this style of financial management, which in extreme cases may lead to over-indebtedness. Using a credit card facilitates careless spending and allows taking new loans, often to repay the old ones. Such behaviour may lead to a debt spiral which means serious financial problems. In addition, young people, people with no income or with income coming from the black market, or with a poor credit history and thus ineligible for bank loans, become customers of unsupervised and unregulated lending institutions (e.g. Provident, Payday) that operate in the shadow banking sector.

The study results are an inspiration for further research. The subject of our study could be expanded to include behaviour analysis for different age groups. A particularly interesting issue seems to be the factors determining the savings and credit decisions among young people, including observations of how their parents' behaviour affect their own attitudes. This knowledge seems to be useful in the context of the effective education of children. Credit and savings decisions are an area highly inspiring for further research. Apart from mental accounting, other significant issues include:

- identification of individuals' behaviour in relation to the windfalls (e.g. bonus or bequest),

- analysis of the specific nature of credit and savings decisions taken by financially excluded people, i.e. those who are ineligible for the products and services of mainstream banking sector and therefore must rely on shadow banking sector products,

- identification and analysis of factors determining specific management styles for personal finances (greed vs. fear, credit vs. savings).

The use of experimental methods might also prove interesting. As a result of their use we might be able to better understand savings and credit decision-making.

\section{REFERENCES}

Abeler, J., Marklein, F., Fungibility, labels, and consumption, Discussion Paper, Centre for Decision Research and Experimental Economics University of Nottingham, no. 2010-13, pp. 1-45, July 2010.

Ainslie G., Specious reward: a behavioral theory of impulsiveness and impulse control, "Psychological Bulletin", Vol. 82, No. 4, 1975.

Baker, H. K., Nofsinger, J. R., Behavioral finance: An overview, [in:] Baker H. K. and Nofsinger J. R. (eds.), Behavioral Finance: Investors, Corporations, and Markets, Hoboken, NJ: John Wiley and Sons, Inc., pp. 3-20, 2010. 
Benartzi, S., Thaler, R. H., Heuristics and biases in retirement savings behavior, "Journal of Economic Perspectives", Vol. 21, Issue 3, pp. 81-104, 2007.

Benartzi, S., Thaler, R. H., Naive diversification strategies in defined contribution saving plans, “American Economic Review”, Vol. 91, No 1, pp. 79-98, 2001.

Bhootra, A., Hur, J., On the relationship between concentration of prospect theory/mental accounting investors, cointegration, and momentum, "Journal of Banking and Finance", Vol. 36, Issue 5, pp. 1266-1275, 2012.

Booth, T., Grimmond, D., Stroombergen, A., Determinants of savings behavior. Research report. Office of the Retirement Commissioner, January, 2000.

Braun M. A., Did the 'homo economicus' mutate to the concept of behavioural finance and economics?, Seminar Paper, GRIN Verlag, 2006.

Card, D., Ransom, M., Pension plan characteristics and framing effects in employee savings behavior, IZA Discussion Paper No. 2939, July 2007.

Davies, S., Easaw, J., Ghoshray, A., Mental accounting and remittances: a study of rural Malawian households, "Journal of Economic Psychology", Vol. 30, Issue 3, pp. 321-334, 2009.

Erat, S., Bhaskaran, S. R., Consumer mental accounts and implications to selling base products and add-ons, "Marketing Science", Vol. 31, Issue 5, pp. 801-818, 2012.

Finney, D.J., Probit analysis, Cambridge University Press, 1971.

Gilboa, I., Postlewaite, A., Schmeidler, D., The complexity of the consumer problem and mental accounting, University of Pennsylvania Working Paper, 2010.

Gilovich, T., Griffin, D., Kahneman D., (eds.), Heuristics and biases: The psychology of intuitive judgment, Cambrigde University Press, 2002.

Gou, Y., Jiang, Y. Li, R., Miao, D., Peng, J., The non-fungibility of mental accounting: A revision, "Social Behavior and Personality", Vol. 41(4), pp. 625-634, 2013.

Graham, F., Isaac, A. G., The behavioral life-cycle theory of consumer behavior: Survey evidence, "Journal of Economic Behavior \& Organization", Vol. 48, Issue 4, pp. 391-401, 2002.

Grinblatt, M., Han, B., Prospect theory, mental accounting, and momentum, "Journal of Financial Economics", Vol. 78, Issue 2, pp. 311-339, 2005.

Hoque, M. Z., Ulku N., Mental budgeting and the financial management of small and medium entrepreneurs, "Cogent Economics \& Finance“, Vol. 5, Issue 1, pp. 1-19, 2017.

Hosmer, D.W., Lemeshow, S., Applied Logistic Regression, New York: John Wiley \& Sons, 2000.

Hosmer, D. W., Lemeshow, S., Goodness-of-fit tests for the multiple logistic regression model, "Communications in Statistics-Theory and Methods", Vol. 10, pp. 1043-1069, 1980.

$\mathrm{Hu}, \mathrm{Y} ., \mathrm{Li}, \mathrm{J} ., \mathrm{Ran}, \mathrm{L} .$, Dynamic pricing for airline revenue management under passenger mental accounting, "Mathematical Problems in Engineering", Vol. 2015, pp. 1-8, 2015.

Kahneman, D., Tversky, A., Prospect theory: An analysis of decision under risk, "Econometrica", Vol. 47, No. 2, pp. 263-292, 1979.

Kahneman, D., Tversky, A., Judgment under uncertainty: Heuristics and biases, "Science", New Series, Vol. 185, No. 4157, pp. 1124-1131, 1974. 
Karlsson, N., Gärling, T., Selart, M., Effects of mental accounting on intertemporal choice, "Göteborg Psychological Research", Vol. 27, No. 5, 1997.

Khandakar, E., Behavioural controversy concerning homo economicus: A Humean perspective, "The Journal of Philosophical Economics", VII:2, pp. 1-29, 2014

Kivetz, R., Advances in research on mental accounting and reason-based choice, "Marketing Letters", Vol. 10, Issue 3, pp. 249-266, 1999.

Kleinbaum, D.G., Klein, M., Logistic regression - a self-learning text (second edition), New York: Springer, 2005.

Koch, A. K., Nafziger, J., Correlates of narrow bracketing, Economics Working Papers, 2016-01, pp. 1-30, 2016, http://econ.au.dk/fileadmin/site_files/filer_oekonomi/Working Papers/Economics/2016/wp16_01.pdf

Koch, A. K., Nafziger, J., Goals and mental accounting. Mimeo, Aarhus University, 2014.

Levav, J., McGraw, A., Emotional accounting: How feelings about money influence consumer choice, "Journal of Marketing Research “, Vol. 46, Issue 1, pp. 66-80, 2009.

Loewenstein, G., Thaler, R. H., Anomalies: Intertemporal choice. "Journal of Economic Perspectives", No. 3(4), pp. 181-193, 1989.

Mazar, N., Plassmann, H., Robitaille, N., Lindner, A., Pain of paying? A metaphor gone literal: Evidence from neural and behavioral science, Rotman School of Management Working Paper No. 2901808, pp. 1-50, 2017.

McFadden, D., Conditional logit analysis of qualitative choice behavior, [in:] Zarembka P., (ed.) "Frontiers in Econometrics“, Academic Press: New York, pp. 105-142, 1974.

Milkman, K., Beshears, J., Mental accounting and small windfalls: evidence from an online grocer, "Journal of Economic Behavior \& Organization", Vol. 71, Issue 2, pp. 384-394, 2009.

Odean, T., Are investors reluctant to realize their losses?, "Journal of Finance", Vol. 53, Issue 5, pp. 1775-1798, 1998.

Prelec, D., Loewenstein, G., The red and the black: Mental accounting of savings and debt, "Marketing Science", Vol. 17, Issue 1, pp. 4-28, 1998.

Rajagopal, P., Rha, J. Y., The mental accounting of time, "Journal of Economic Psychology", Vol. 30, Issue 5, pp. 772-781, 2009.

Reinholtz, N., Bartels, D. M., Parker, J. R., On the mental accounting of restricted-use funds: how gift cards change what people purchase, "Journal of Consumer Research", Vol. 42, Issue 4, pp. 596-614, 2015.

Ranyard, R., Hinkley, L., Williamson, J., McHugh, S., The role of mental accounting in consumer credit decision processes, "Journal of Economic Psychology", Vol. 27, Issue 4, pp. 571-588, 2006.

Ritter, J. R., Behavioral finance, "Pacific-Basin Finance Journal", Vol. 11, No. 4, pp. 429437, 2003.

Schelling, T. C., Egonomics, or the art of self-management, "American Economic Review", Vol. 68, Issue 2, pp. 290-294, 1978.

Seiler, M. J., Seiler, V. L., Lane, M. A., Mental accounting and false reference points in real estate investment decision-making, "Journal of Behavioral Finance", Vol. 13, Issue 1, pp. 17-26, 2010. 
Selart, M., Karlsson, N., Gärling, T., Self-control and loss aversion in intertemporal choice, "Journal of Socio-Economics", Vol. 26, No. 5, pp. 513-424, 1997.

Shafir, E., Thaler, R. H., Invest now, drink later, spend never: the mental accounting of delayed consumption, "Journal of Economic Psychology", Vol. 27. No 5, pp. 694-712, 2006.

Shanti, J. C., Mental accounting in consumer decision making (Accountants and nonaccountants) related to discount coupons, "Advanced Science Letters", Vol. 23, No. 1, pp. 670-673(4), 2017.

Shefrin, H., Beyond greed and fear: Understanding behavioral finance and the psychology of investing. Oxford: Oxford University Press Inc., 2002.

Shefrin, H., Thaler R. H, Mental accounting, saving, and self-control, [in:] Camerer C. F. Loewenstein G., Rabin M. (eds.), Advances in behavioural economics, pp. 395-428, 2004.

Swacha-Lech, M., Zagadnienie krótkowzroczności jednostek $w$ kontekśsie decyzji dotyczacych gromadzenia oszczędności, "Annales Universitatis Mariae Curie-Skłodowska. Sectio H, Oeconomia", Vol. 46, No. 4, pp. 795-802, 2012.

Thaler, R. H., Mental accounting and consumer choice, "Marketing Science", Vol. 4, Issue 3, pp. 199-214, 1985.

Thaler, R. H., Anomalies. Saving, fungibility, and mental accounts, "Journal of Economic Perspectives", Vol. 4, Issue 1, pp. 193-205, 1990.

Thaler, R. H., Doing economics without Homo Economicus, [in:] Medema S. G., Samuels W. J. (eds.), "Foundations of Research in Economics: How do Economists do Economics?", Cheltenham, Edward Elgar Publishing, pp. 227-237,1998.

Thaler, R. H., Mental accounting matters, “Journal of Behavioral Decision Making”, Vol. 12, Issue 3, pp. 183-206, 1999.

Thaler, R. H., The winner's curse: Paradoxes and anomalies of economic life. Simon and Schuster, 2012.

The average salary in the second quarter of 2013, Zakład Usług Społecznych, http://www.zus.pl/default.asp?p=1\&id=24 (accessed 13.05.2017).

Received: July 2017, revised: March 2019 